\title{
Retraction Note to: Extreme rainfall response based on SAR imaging and home sports training effect
}

\author{
Yujuan $\mathrm{Huo}^{1} \cdot$ Weiqun Huang ${ }^{1}$
}

Published online: 3 November 2021

(c) Saudi Society for Geosciences 2021

Retraction Note to: Arabian Journal of Geosciences (2021) 14: 1495 https://doi.org/10.1007/s12517-021-08008-z

The Editor-in-Chief and the Publisher have retracted this article because the content of this article is nonsensical. The peer review process was not carried out in accordance with the Publisher's peer review policy. The authors have not responded to correspondence regarding this retraction.

The original article can be found online at https://doi.org/10.1007/ s12517-021-08008-z.

Weiqun Huang

hw32937296@163.com

1 Nanchang University, Nanchang City 330031,

Jiangxi Province, China 